\title{
State of Life Satisfaction and Physical Fitness in Elderly through Gateball Sports in Terms of Economics
}

\author{
Sufyar Mudjianto* \\ Department of Physical Education \\ Universitas Pendidikan Indonesia \\ Bandung, Indonesia \\ *sufyarfpok@upi.edu
}

\begin{abstract}
This study departs from elderly people who experience problems with the level of life satisfaction and physical fitness. The research design used is causal-comparative, namely knowing how much the state of life satisfaction and physical fitness in elderly through gateball sports in terms of economics. The study sample was an elderly gateball athlete PELATCAB PORDA XII Jawa Barat 2018 Kota Bandung numbering> 100 athletes located in the training center. The sampling technique uses Random Sampling. The instrument used was using a life satisfaction questionnaire and a senior fitness test. Analysis of the data in this study using SPSS series 23 with the test equipment used include: normality test with kolmogorovsmirnov, homogeneity test with lavene statistics, and hypothesis testing with $t$ test (independent sample $t$-test) to determine the differences between sample groups. Based on the questions and objectives of this study through relevant research with higher levels of physical activity and fitness, the risk of death is lower and older adults experience greater life satisfaction if they are involved in physical activity than those who are less involved in physical activity.
\end{abstract}

Keywords—elderly; life satisfaction; physical fitness

\section{INTRODUCTION}

The existence of the elderly cannot be ruled out in the family, community, nation and state life. Concern for the welfare of the elderly contained in the Undang-Undang Republik Indonesia No. 13 of 1998 concerning Elderly Welfare. Recreational activities have been recommended as a means to improve the health and well-being of older adults McAuley \& Rudolph [1].

Participation in recreational activities plays an important role in improving the quality of life and life satisfaction among older adults $[1,2]$. These positive results are closely related to successful aging [3]. The main contribution of free time involvement to successful aging is that recreational activities offer a context in which older adults can improve their physical function, increase positive feelings and emotions, and promote social interaction [4-6]. For example, Orsega-Smith, et al. analyzed the physical and psychosocial characteristics of older adults who participated in community-based training programs and presented that those who participated more often received better physical, psychological, and social benefits than those who did not participate [6].

In older adults, physical fitness directly affects the functional independence of Garatachea and Lucia [7]. Physical activity (physical activity) is considered as one of the most important health indicators that produce benefits for all large groups of ages, especially older adults. In such age groups, the benefits can be attributed to increased physical fitness and prevention of functional loss of Henwood and Taaffe [8]. Research shows that physical fitness is closely related to quality of life related to health among healthy parents [9]. Better physical fitness is very important to carry out tasks and to participate and enjoy the social and cultural life of World Health Organization [10].

World Health Organization throughout the world, one in four adults do not get enough physical activity (physical activity) for health benefits [11]. Lack of physical activity (physical activity) is one of the most modifiable risk factors for the development of chronic diseases that are not contagious [12].

Warburton, Charlesworth, Ivey, Nettlefold, and Bredin concluded that there is a clear dose-response relationship between physical activity and all causes of death and physical activity and several health indicators [13]. The effect of physical activity (physical activity) on mental health seems to be related to a number of factors including the type of activity, the duration of the activity carried out, and the intensity at which the activity is carried out. For example, research shows that, among teenagers, because participation in physical activity (physical activity) decreases, life satisfaction also decreases [14], Higher life satisfaction scores were reported in young adults who participated in physical activity (physical activity) [15] and older adults participate in most leisure time activities reporting the highest life satisfaction [16]. Hai-Peng $\mathrm{T}$, Toyoshima $\mathrm{S}$, Okamoto $\mathrm{A}$, et al. reported that changes in ability in walking movements were influenced by climbing stairs, walking and playing gateball [17]. It has been reported that gateball can help parents to develop human relationships through socializing with others [18]. 
This research was conducted to determine the level of life satisfaction and physical fitness in the elderly through gateball sports in terms of economics for the elderly who experience constraints on the level of life satisfaction and physical fitness.

\section{METHOD}

The research design used in this study is the basic causalcomparative designs. Fraenkel the basic causal-comparative design involves selecting two or more groups that differ on particular variable of interest and comparing them on another variable or variables [19].

In this study participant, as object of research is the elderly gateball athlete PELATCAB PORDA XII Jawa Barat 2018 Kota Bandung.

Instrument or measuring instrument using a life satisfaction questionnaire adapted from Diener, Emmons, Larson, and Griffin [20] with a scale by Thogersen-Ntoumani and Fox [21], consisting of five items measured on a 7-point Likert scale starting from 1 is strongly disagree until 7 namely strongly agree. An example is 'In many ways, my life is closely related to my ideals', and several studies have shown adequate validity and reliability for this scale as well as senior physical fitness tests (the senior fitness test), individuals completed 7 items from the senior fitness test. Rikli and Jones included 8-foot-upand-go physical dexterity and dynamic balance tests, standing chair test (30-second chair stand), which assesses the strength and endurance of the lower body muscles of the arm curl, which is assessed by the strength of the arm muscles, especially the biceps, chair sit-and-reach, 2- minute step test; 6minute walk, and back scratch test that assesses the flexibility of the upper body, especially the shoulder [22].

\section{RESULTS AND DISCUSSION}

In general, the more often a person is physically active, the better his physical abilities. This is due to the adaptation of the physiological system, especially in the neuromuscular system to coordinate movement, the cardiopulmonary system to more effectively distribute oxygen and nutrients around the body, and metabolic processes that mainly regulate the metabolism of glucose and fatty acids, which collectively increase overall aerobic power and physical ability [23]. Inactivity is a major cause of poor physical fitness and illness at an older age, at least equal to the effects of smoking, excessive drinking and obesity [24]. For example, those who retire from work are more likely than those who continue to work to change to low levels of physical activity from high and middle levels and people aged 70-79 years are about half as likely as those aged 50 to 59 years to get involved when high level of physical activity [25]. Individuals> 80 years old are more than $50 \%$ smaller than those in their early 50s to engage in sports or want to increase their level of activity. With a higher level of activity and physical fitness, the risk of death is low [26].

Cross-sectional and prospective studies examining the relationship between individuals with physical activity and life satisfaction in older adults found that more active people generally tended to experience greater life satisfaction compared to less active peers [27]. Only one study to date has simultaneously investigated the relationship between physical activity and life satisfaction at the level between and within older adults [28]. Older adults experience greater life satisfaction if they are engaged in physical activity than those who are less involved in physical activity [29].

\section{CONCLUSION}

Based on the questions and objectives of this study through relevant research with higher levels of physical activity and fitness, the risk of death is lower and older adults experience greater life satisfaction if they are involved in physical activity than those who are less involved in physical activity.

\section{REFERENCES}

[1] E. McAuley, and D. Rudolph, "Physical activity, aging, and psychological well-being". Journal of Aging Physical Activity, vol. 3 (1), pp. 67-96, 1995

[2] D.L. Gill, K. Williams, L. Williams, B.D. Butki, and B.J. Kim, Physica activity and psychological well-being in older women. Women's Health issues, 7(1), 3-9, 1997.

[3] C.A. Brown, F.A. McGuire, and J. Voelkl, "The link between successful aging and serious leisure". International Journal of Aging and Human Development, vol. 66 (1), pp. 73-95, 2008.

[4] D. Leigey, J. Irrgang, K. Francis, P. Cohen, and V. Wright, "Participation in high-impact sports predicts bone mineral density in senior Olympic athletes". Sportss Health: A Multidisciplinary Approach, vol. 1(6), pp. 508-513, 2009.

[5] J.L. McCrory, A.J. Salacinski, S.E. Hunt, and S.L. Greenspan, "Thigh muscle strength in senior athletes and healthy controls". The Journal of Strength \& Conditioning Research, vol. 23 (9), pp. 2430-2436, 2009.

[6] E. Orsega-Smith, L.L. Payne, and G. Godbey, "Physical and psychosocial characteristics of older adults who participate in a community-based exercise program". Journal of Aging \& Physical Activity, vol. 11 (4), pp. 516-531, 2003.

[7] N. Garatachea and A. Lucía, "Genes and the ageing muscle: a review on genetic association studies". Age, vol. 35, pp. 207-233, 2013.

[8] T.R. Henwood, and D.R. Taaffe, "Short-term resistance training and the older adult: the effect of varied programmes for the enhancement of muscle strength and functional performance". Clin Physiol Funct Imaging, vol. 26, pp. 305-313, 2006

[9] L.S. Acree, J. Longfors, A.S. Fjeldstad, C. Fjeldstad, B. Schank, K.J. Nickel, P.S. Montgomery, and A.W. Gardner, "Physical activity is related to quality of life in older adults". Health Qual Life Outcomes, vol. 4, pp. 1-6, 2006.

[10] World Health Organization, Active Ageing, a Policy Framework. Geneva, World Health Organization, 2010

[11] World Health Organization, Physical activity fact sheet, 2015, Retrieved from http://www.who.int/mediacentre/factsheets/fs385/en/.

[12] F.W. Booth, and S.J. Lees, "Fundamental questions about genes, inactivity, and chronic diseases". Physiological genomics, vol. 28(2), pp. 146-157, 2007.

[13] D.E. Warburton, S. Charlesworth, A. Ivey, L. Nettlefold, and S.D.S Bredin, "A systematic review of the evidence for Canada's physica activity guidelines for adults". International Journal of Behavioral Nutrition and Physical Activity, 7, Article 39, 2010.

[14] G.A. Kaplan, N.B. Lazarus, R.D. Cohen, and D. Leu, "Psychosocial factors in the natural history of physical activity". American Journal of Preventive Medicine, vol. 7, pp. 12-17, 1991

[15] T. Tasiemski, P. Kennedy, B.P. Gardner, and N. Taylor, "The association of sports and physical recreation with life satisfaction in a community sample of people with spinal cord injuries". NeuroRehabilitation, vol. 20, pp. 253-265, 2005 
[16] J. Heo, R.A. Stebbins, J. Kim, and I. Lee, "Serious leisure, life satisfaction, and health of older adults". Leisure Sciences, vol. 35, pp. 16-32, 2013

[17] T. Hai-Peng, S. Toyoshima, A. Okamoto et al., "An eight-year follow up study of walking movement in elderly". Society of Biomechanisms, vol. 31 (1), pp. 51-55 (in Japanese), 2007.

[18] Y. Sawada, R. Shinohara, Y. Sugisawa et al., "Maintenance of physical function and related factors for community dwelling elderly: a nine-year follow-up study”. J Phys Ther Sci, vol. 21, pp. 245-251, 2009.

[19] M.L. Mendillo, S. Santagata, M. Koeva, G.W. Bell, R. Hu, R.M. Tamimi, and S. Lindquist, "HSF1 drives a transcriptional program distinct from heat shock to support highly malignant human cancers". Cell, vol. 150(3), pp. 549-562, 2012.

[20] E. Diener, R.A. Emmons, R.J. Larson, and S. Griffin, "The satisfaction with life scale". Journal of Personality Assessment, vol. 49, pp. 71-75, 1985.

[21] C. Thogersen-Ntoumani, and K.R. Fox, "Physical activity and mental well-being typologies in corporate employees: A mixed method approach". Work \& Stress, vol. 19 (1), pp. 50-67, 2005.

[22] R.E. Rikli, and C.J. Jones, "Senior fitness test manual". Champaign, Human Kinetics, 2001.
[23] M.S. Jamie, F.P. David, J. Dean, N. James, P. Neil, and D. Hans, "Physical activity in older age: perspectives for healthy ageing and frailty". Springer, 2016.

[24] I.M. Lee, E.J. Shiroma, F. Lobelo, P. Puska, S.N. Blair, P.T Katzmarzyk, "Effect of physical inactivity on major non- communicable diseases worldwide: an analysis of burden of disease and life expectancy". Lancet 380:219-229, 2012.

[25] K. Matthews, P. Demakakos, J. Nazroo, and A. Shankar, "The evolution of lifestyles in older age in England". Wave, vol. 6, pp. 51, 2014

[26] D.I. Feldman, M.H. Al-Mallah, S.J. Keteyian, C.A. Brawner, T. Feldman, R.S. Blumenthal, and M.J. Blaha, "No evidence of an upper threshold for mortality benefit at high levels of cardiorespiratory fitness". J Am Coll Cardiol, vol. 65, pp. 629-630, 2015.

[27] S. Elavsky, and E. McAuley, "Physical activity, symptoms, esteem, and life satisfaction during menopause". Maturitas, vol. 52, pp. 374385 , 2005.

[28] J.P. Maher, A.L. Pincus, N. Ram, and D.E. Conroy, "Physical activity and life satisfaction acrossadulthood". Developmental Psychology, 2015.

[29] K.E. Powell, A.E. Paluch, and S.N. Blair, "Physical activity for health: What kind? How much? How intense? On top of what?" Annual Review of Public Health, vol. 32, pp. 349-365, 2011. 